\title{
ANALISIS FAKTOR-FAKTOR KEBERMANFAATAN, KEMUDAHAN DAN KEPERCAYAAN TERHADAP INTENSI PENGGUNAAN APLIKASI UC STUDENT
}

\author{
Om Ake Ico Simeru ${ }^{1}$, Rinabi Tanamal ${ }^{2}$ \\ ${ }^{1)}$ Information System For Business/Fakultas Teknologi Informasi, Universitas Ciputra \\ ${ }^{2)}$ Information System For Business/Fakultas Teknologi Informasi, Universitas Ciputra
}

Diterima 6-7-2020 / Disetujui 7-9-2020

\begin{abstract}
The development of technology, especially in the creation of existing applications, causes users to receive the latest information. However, not all information technology is accepted by all parties, due to inconsistency with existing needs. In this research, explain the intention of using the UC Student application where the variables used are the perception of usefulness, perception of ease, trust and quality of information. The research uses the theory of Technology Acceptance Model (TAM) to determine what factors affect the use Of the UC Student application. The instrument used in this research is a questionnaire (angket), which is distributed online to 100 respondents who have used the UC Student application. Data processing by using SPSS obtained result from regression number as follows $Y=1.279$ $+0.412 x_{1}+0.176 x_{2}+0.093 x_{3}+0.036 x_{4}$, variable perceived usefulness has the greatest influence on intention to use UC Student application, and variable perceived ease of use gives a positive impact on the UC student intention to use application. In this research perceived variable usefulness have a major influence on the Intention to use UC Student Application.
\end{abstract}

Keywords: TAM, UC Student application, perception of usefulness, perception of ease, trust, quality information.

\begin{abstract}
ABSTRAK
Perkembangan teknologi khususnya pada pembuatan aplikasi yang ada menyebabkan pengguna dapat menerima informasi yang terbaru. Akan tetapi tidak semua teknologi informasi diterima oleh semua pihak, dikarenakan ketidak sesuaian dengan kebutuhan yang ada. Pada penelitian yang dilakukan ini menjelaskan tentang intensi penggunaan aplikasi UC Student yang dimana variabel yang digunakan adalah persepsi kebermanfaatan, persepsi kemudahan, kepercayaan dan kualitas informasi. Penelitian ini menggunakan teori Technology Acceptance Model (TAM) untuk mengetahui faktor apa yang berpengaruh terhadap intensi penggunaan aplikasi UC Student. Instrumen yang digunakan dalam penelitian ini adalah kuesioner (angket), yang disebarkan secara online kepada 100 responden yang pernah menggunakan aplikasi UC Student. Pengolahan data dengan menggunakan SPSS diperoleh hasil dari persamaaan regresi sebagai berikut $Y=1,279+0,412 X_{1}+0,176 X_{2}+0,093 X_{3}+0,036 X_{4}$, Variabel perceived usefulness memberikan pengaruh paling besar terhadap intention to use aplikasi UC Student, dan Variabel perceived ease of use memberikan pengaruh positif terhadap intention to use aplikasi UC Student. Dalam penelitian ini variabel perceived usefulness memiliki pengaruh besar terhadap intention to use aplikasi UC Student.
\end{abstract}

Kata Kunci: TAM, Aplikasi UC Student, Persepsi Kebermanfaatan, Persepsi Kemudahan, Kepercayaan, Kualitas Informasi.

\footnotetext{
*Korespondensi Penulis:

E-mail: r.tanamal@ciputra.ac.id,
} 


\section{PENDAHULUAN}

Pendidikan adalah salah satu hal yang memiliki pengaruh besar terhadap kehidupan, sehingga dengan adanya pendidikan maka masyarakat akan banyak mengetahui hal-hal yang baru. Pendidikan yang ada di Indonesia sekarang berkembang dengan sangat cepat dan pendidikan tidak lepas dengan yang namanya teknologi informasi. Dengan adanya teknologi informasi di Indonesia dapat meningkatkan mutu pendidikan. Teknologi informasi sudah sangat banyak berkembang dan memberikan beberapa manfaat yang positif. Meskipun itu tidak terlepas dari hal-hal negatif yang ditimbulkan akibat penyalahgunaan informasi.

Menurut (Sartika \& Yuliantoro, 2019) teknologiinformasi merupakan salah satu hal yang dimanfaatkan untuk mengelola data yaitu dengan melakukan pemrosesan data, memperoleh data, menyusun, memanipulasi serta membenahi data dengan tujuan untuk mendapatkan informasi yang berbobot serta bermanfaat bagi penerima informasi. Pada zaman milenial ini, teknologi informasi dan komunikasi (TIK) berkembang pesat bersinggungan dengan hampir seluruh lapisan masyarakat, tidak terkecuali siswa. Salah satu bentuk TIK (teknologi informasi dan komunikasi) yang familiar di tengah kaum pelajar adalah telepon seluler. Data tahun 2018 ada sekitar 67\% siswa yang berusia 5 sampai 24 tahun memakai telepon seluler. Dilihat dari berbagai jenjang pendidikan, besar persentase (\%) pendidikan seseorang (siswa) dipengaruhi oleh tingkat pendidikan yang dimiliki oleh siswa tersebut dalam menggunakan telpon seluler (Rachmawati et.all., 2018).

Era telepon pintar atau sering disebut smartphone didukung dengan ketersediaan jaringan internet membukakan akses informasi dan komunikasi yang cepat. Mudahnya mengakses informasi mendorong sistem pengajaran menjadi lebih terbuka akan pengetahuan tambahan (wawasan) yang diperoleh dari luar bangku sekolah. Siswa pun bersinggungan dengan internet dalam kesehariannya, entah untuk menyelesaikan tugas sekolah ataupun untuk kepentingan lainnya(Rachmawati et.all., 2018).

Di satu sisi internet memudahkan siswa untuk menambah wawasan yang mendukung materi pelajaran di sekolah. Di sisi lain aplikasi internet yang sifatnya entertaining cenderung melenakan sehingga menurunkan prestasi siswa di sekolah. Siswa yang menggunakan internet selayaknya disikapi dengan bijak, misalnya dengan pendampingan orang tua(Rachmawati et.all., 2018).

Suatu sistem yang sukses diimplementasikan adalah sistem yang mempunyai kinerja yang baik yang berarti bahwa sistem tersebut mempunyai kemampuan hardware dan software dalam mendukung sistem dan kemudahan dalam pemakaiannya yang berdampak pada peningkatan kinerja individu maupun organisasi (Tulodo \& Solichin, 2019).

Aplikasi pada umumnya didefinisikan sebagai salah satu proses dari manual kemudian diubah menjadi komputer, serta mendesain suatu program dengan tujuan data yang diolah memiliki daya guna secara maksimal. Aplikasi juga harus memiliki user-friendly yang baik agar pengguna dapat mudah menggunakan aplikasi tersebut. Dalam melakukan pengembangan aplikasi yaitu dengan mengikuti kebutuhan lingkungan sekitar. Jika aplikasi semakin berkembang maka aplikasi tersebut dapat memberikan dampak yang lebih baik kepada setiap pihak yang menggunakan aplikasi tersebut.

Tidak semua teknologi dapat diterima oleh semua pihak, teknologi yang diciptakan terkadang dapat diterima dan tolak oleh masyarakat dikarenakan 
beberapa hal. Penerimaan teknologi terhadap pemakaian dan dapat diterima ataupun ditolak oleh masyarakat atau pelajar dapat diperkirakan dengan memanfaatkan teori Technology Acceptance Model (TAM) diperkenalkan atau dikemukakan pertama kali oleh Davis (1989), teori tersebut diprediksi probabilitas dari teknologi yang diciptakan dapat dibentuk dalam kelompok individu atau institusi. Technology Acceptance Model dibangun dengan tanggapan dari Fishbein dan Ajzen pada tahun 1975 mengenai Theory of Reasoned Action(Sukma, Hadi, \& Nikmah, 2019).

Rumusan masalah dibuat berdasarkan dari latar belakang diatas dalam penelitian ini diantaranya adalah:

1. Apakah faktor Perceived Usefulness (PU) memberikan pengaruh signifikan terhadap Intention to Use (ITU) aplikasi UC Student?

2. Apakah faktor Perceived Ease of Use (POU) memberikan pengaruh signifikan terhadap Intention to Use (ITU) aplikasi UC Student?

3. Apakah faktor Trust (TU) berpengaruh signifikan positif pada Intention to Use (ITU) aplikasi UC Student?

4. Apakah Quality of Information (QI) berpengaruh signifikan positif pada Intention to Use (ITU) aplikasi UC Student?

Berdasarkan dari rumusan masalah diatas, maka tujuan dari penelitian ini adalah:

1. Untuk mengetahui pengaruh variabel Perceived Usefulness (PU) terhadap Intention to Use (ITU) aplikasi UC Student.

2. Untuk mengetahui pengaruh dari variabel Perceived Ease of Use (POU) terhadap variabel dependen yaitu Intention to Use (ITU) aplikasi UC Student.

3. Untuk mengetahui pengaruh variabel Trust (TU) terhadap Intention to Use (ITU) aplikasi UC Student.
4. Untuk mengetahui pengaruh Quality of Information (QI) terhadap Intention to Use (ITU) aplikasi UC Student.

5. Untuk mendapatkan faktor-faktor yang dapat memberikan pengaruh paling besar terhadap Intention to Use (ITU) aplikasi UC Student.

\section{METODE PENELITIAN}

Pada penelitian ini metode yang digunakan adalah metode penelitian kuantitatif. Menurut buku (Noor, 2011) penelitian kuantitatif merupakan suatu metode dalam melakukan penelitian yang digunakan untuk melakukan pengujian terhadap teori-teori tertentu dengan meneliti hubungan dari variabel dalam penelitian. Variabel - variabel pada penelitian akan diukur dengan menggunakan instrumen penelitian, sehingga data yang terdiri dari suatu angka - angka dapat dilakukan analisis dengan berdasarkan prosedur statistik.

\section{Technology Acceptance Model(TAM)}

Secara umum teori yang diterima secara luas sebagai kerangka kerja untuk memahami proses penggunaan teknologi informasi disebut Technology Acceptance Model (TAM). Pada model ini dibuktikan dengan penjelasan beberapa varian dalam niat perilaku pengguna yang terkait dengan adopsi teknologi informasi dan penggunaan di berbagai kontek (Rhee, 2019).

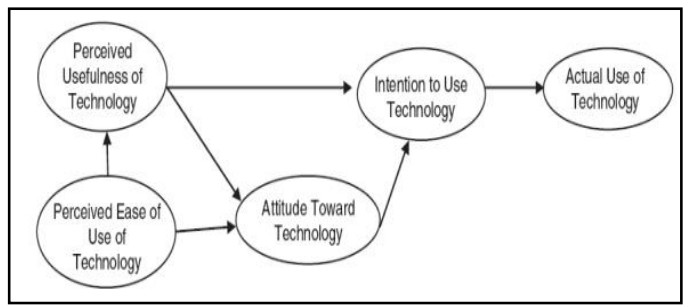

Gambar 1 Tachnology Acceptance Model (TAM) 
Technology Acceptance Model (TAM) adalah pola yang memiliki arti sebagai memperkirakan penerimaan teknologi oleh pengguna dan dikaitkan dengan pengguna teknologi untuk pekerjaan. Dalam jurnal (Sukma, Hadi, \& Nikmah, 2019)Technology Acceptance Model (TAM) dikembangkan untuk mengemukakan teori penggunaan teknologi komputer oleh Davis pada tahun 1989.

Berdasarkan dari teori yang digunakan dalam penelitian ini, maka model analisis atau model yang digunakan pada penelitian ini adalah:

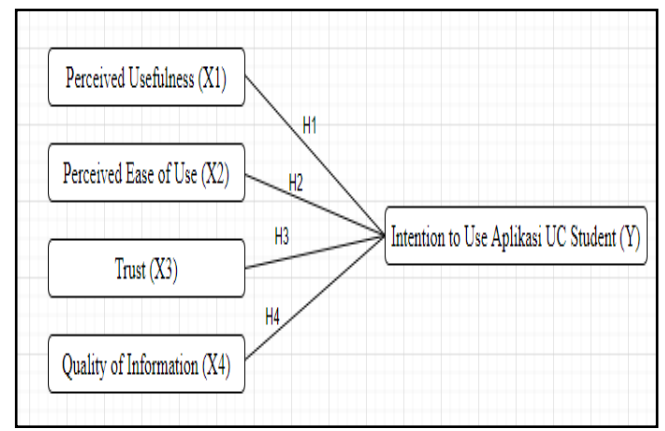

Gambar 2 Model Analisis

Penjelasan:

1. Variabel bebas (Independen) yaitu Perceived Usefulness (X1), Perceived Ease of Use (X2), Trust (X3)dan Quality of Information (X4).

2. Variabel terikat (Dependen) yaitu Intention to Use Aplikasi UC Student.

\section{Intention to Use}

Intensi merupakan suatu kemauan, kecenderungan atau niat seseorang untuk melakukan perilaku tertentu. Teori perilaku terencana dan pengembangan teori dari tindakan beralasan dapat dijelaskan dari pengertian intensi tersebut (Sukma, Hadi, \& Nikmah, 2019).

\section{Perceived Usefulness}

Persepsi kebermanfaatan (perceived usefulness) sistem teknologi informasi merupakan pengguna yang mengharapkan manfaat yang diperoleh saat mengerjakan sebuah tugas. Apabila teknologi yang digunakan bermanfaat secara positif bagi pengguna, maka seseorang akan menggunakan teknologi informasijurnal(Triana, Kurniawan, \& Dewi, 2018).

Perceived usefulness dapat diartikan bahwa penggunaan situs media sosial dapat dipercaya serta dapat memenuhi kebutuhan setiap individu dengan suatu tujuan(Sukma, Hadi, \& Nikmah, 2019).

\section{Perceived Ease of Use}

Persepsi kemudahan merupakan salah satu indikator kunci yang menentukan penerimaan individual terhadap sistem informasi yang digunakan. Artinya bahwa dapat mengungkapkan sejauh mana niat seorang individu dalam penggunaan teknologi informasi adalah mudah untuk dioperasikan atau digunakan(Triana, Kurniawan, \& Dewi, 2018).

Persepsi Kemudahan didefinisikan sebagi suatu kemudahan penggunaan (dirasakan kemudahan dalam penggunaan) sebagaimana suatu kepercayaan dalam penggunaan sistem tersebut akan mengurangi upaya seseorang untuk melakukan sesuatu yang lebih(Rinabi, 2019).

\section{Trust}

Kepercayaan (trust) merupakan salah satu dasar dari transaksi bisnis yang melibatkan dua pihak atau lebih yang masing-masing dari mereka memiliki kepercayaan satu dengan yang lain. Kepercayaan yang dibangun dari awal 
dapat dibuktikan dan tidak bisa dikenali oleh pihak lain. Kepercayaan sudah dianggap sebagai dorongan dalam bentuk transaksi antara penjual dengan pembeli sehingga kepuasan customer dapat direalisasikan seperti harapan dari pihak yang terkait(Rinabi, 2019).

\section{Quality of Information}

Kualitas informasi (quality of information) merupakan salah satu dari tingkat informasi yang memiliki karakteristik isi tersendiri, bentuk, dan waktu yang dapat memberikan nilai bagi para pengguna informasi. Kualitas terbaik dari informasi akan dapat meningkatkan kegunaan serta dapat meningkatkan minat penggunaan dari sistem informasi (Rukmiyati \& Budiartha, 2016).

Kualitas produk yang dihasilkan dapat menciptakan atau menunjukkan kualitas informasi. Semakin baik quality of information yang diberikan akan semakin mempengaruhi keputusan yang diambil oleh pengguna(Tulodo \& Solichin, 2019).

Menurut (Rozieqy \& Arifin, 2018), menjelaskan bahwa kualitas informasi dikategorikan menjadi tiga (3) bagian, diantaranya adalah;

1. Akurat (accuracy), merupakan informasi yang dituntut mampu menerangkan suatu keadaan atau kondisi yang pasti dan bebas dari kekeliruan.

2. Tepat waktu (timeliness), yaitu tidak pernah terlambat dalam menyajikan suatu informasi yang terupdate.

3. Relevan (relevancy), yang berarti informasi yang diberikan tersebut sesuai dengan keinginan dan dapat berguna bagi pemakainya.
Perumusan hipotesis merupakan suatu jawaban sementara dari rumusan masalah dalam penelitian (Siregar, Dalimunthe, \& Trijuniyanto, 2019).Berdasarkan model analisis pada gambar 2, maka perumusan hipotesis dalam penelitian ini adalah sebagai berikut:

H1: Perceived usefulness berpengaruh terhadap intention to use aplikasi $U C$ Student(Rahmawati \& Narsa, 2019).

$\mathrm{H} 2$ : Perceived ease of use berpengaruh signifikan positif terhadap intention to use aplikasi UC Student(Rozieqy \& Arifin, 2018).

H3: Trust memiliki pengaruh positif terhadap intention to useaplikasi UC Student(Rinabi, 2019).

H4: Quality of information berpengaruh signifikan positif terhadap intention to use aplikasi UC Student(Rozieqy \& Arifin, 2018).

\section{Metode Pengumpulan Data}

Penelitian pengaruh Technology Acceptance Model (TAM) pada penggunaan aplikasi UC Student, peneliti menerapkan sebuah metode dalam proses pengumpulan data yaitu dengan menggunakan kuesioner yang berbasis online dengan menggunakan platform dari Google, yaitu google form.

Skala likert merupakan sebuah skala yang dirancang untuk mengetahui tingkat keakuratan subjek dalam hal setuju atau tidak setuju dari pernyataan yang digunakan dalam penelitian. Hasil dari setiap responden yang diterima oleh peneliti akan dilakukan pengukuran dengan menggunakan alat ukuran skala Likert(Rinabi, 2019).Terdapat lima poin dalam skala likert ini, lima poin digunakan untuk menghitung skor yang diperoleh dari responden, sebagai berikut:

\section{Perumusan Hipotesis}


Tabel 1Skala Likert

\begin{tabular}{|lc|c|}
\hline \multicolumn{2}{|c|}{ Jawaban } & Skor \\
\hline Sangat Setuju (SS) & 5 \\
\hline Setuju (S) & 4 \\
\hline Netral (N) & 3 \\
\hline Tidak Setuju (TS) & 2 \\
\hline Sangat Tidak Setuju (STS) & 1 \\
\hline
\end{tabular}

Populasi merupakan kumpulan atau total dari koleksi individu, barang, kelompok, masyarakat, atau unit lain yang di pahami dan diteliti (Bergin, 2018).

Menurut (Rinabi, 2019) populasi mengacu pada sekelompok orang yang merupakan acuan peristiwa yang menarik bagi peneliti, sehingga peneliti ingin menganalisis kejadian atau fenomena yang ada. Definisi ini menunjukkan bahwa dalam data populasi tidak hanya manusia dan jumlah yang dipelajari, melainkan semua karakteristik benda-benda alami yang dimiliki bagian subjek dan objek pada penelitian.

Sampel yang digunakan hanya beberapa atau sebagian dari populasi yang diambil dan tidak semua dari populasi digunakan. Sehingga dengan mengambil sebagian dari data populasi, para peneliti dapat menarik suatu kesimpulan yang bisa digeneralisasikan oleh peneliti (Rinabi, 2019).

Pada teknik pengumpulan data yang digunakan pada penelitian ini adalah teknik Non Probability Sampling yang diaman jenis sampling yang digunakan adalah Judgment Sampling(Rinabi, 2019).Definisi Non Probability Samplingadalah suatu cara yang dimana proses pengambilan beberapa sampel tidak memiliki peluang yang sama dari setiap populasi yang digunakan sebagai sampel.Pemilihan sampel pada penelitian ini adalah berdasarkan pada kriteria-kriteria sebagai berikut:

1. Mahasiswa yang aktif dan terdaftar di kampus Universitas Ciputra.
2. Pernah menggunakan atau mengunduh aplikasi UC Student

3. Jumlah sampel yang ditetapkan pada penelitian ini adalah 104 orang (sampel).

Analisis data dilakukan dengan menggunakan software SPSS dengan analisis regresi linear berganda.

\section{Instrumen Penelitian}

Tabel 2 Variabel Perceived Usefulness

\begin{tabular}{|c|l|}
\hline No & \multicolumn{1}{|c|}{ Pernyataan } \\
\hline 1 & $\begin{array}{l}\text { Penempatan informasi pada aplikasi } \\
\text { UC Student mempermudah saya } \\
\text { dalam mengakses informasi. }\end{array}$ \\
\hline 2 & $\begin{array}{l}\text { Aplikasi UC Student dapat } \\
\text { memenuhi kebutuhan saya dalam } \\
\text { mendapatkan informasi tentang } \\
\text { perkuliahan }\end{array}$ \\
\hline 3 & $\begin{array}{l}\text { Aplikasi UC Student meningkatkan } \\
\text { efektivitas saya dalam mengakses } \\
\text { jadwal perkuliahan. }\end{array}$ \\
\hline
\end{tabular}

Tabel 3Variabel Perceived Ease of Use

\begin{tabular}{|c|l|}
\hline No & \multicolumn{1}{|c|}{ Pernyataan } \\
\hline 1 & $\begin{array}{l}\text { Saya dapat mengakses aplikasi } \\
\text { UC Student dengan mudah, kapan } \\
\text { dan dimana saja. }\end{array}$ \\
\hline 2 & $\begin{array}{l}\text { Saya tidak perlu menghabiskan } \\
\text { waktu yang lama untuk } \\
\text { memikirkan bagaimana cara } \\
\text { menggunakan aplikasi } U C \\
\text { Student. }\end{array}$ \\
\hline 3 & $\begin{array}{l}\text { Mudah bagi saya untuk terampil } \\
\text { dalam menggunakan aplikasi } U C \\
\text { Student untuk memenuhi apa yang } \\
\text { saya inginkan. }\end{array}$ \\
\hline 4 & $\begin{array}{l}\text { Tampilan antarmuka aplikasi } U C \\
\text { Student jelas dan mudah } \\
\text { dipahami. }\end{array}$ \\
\hline
\end{tabular}


Tabel 4 Variabel Trust

\begin{tabular}{|c|l|}
\hline No & \multicolumn{1}{|c|}{$\begin{array}{c}\text { Pernyatan } \\
\text { (Variabel Trust) }\end{array}$} \\
\hline 1 & $\begin{array}{l}\text { Aplikasi UC Student dapat } \\
\text { dipercaya oleh mahasiswa } \\
\text { universitas Ciputra. }\end{array}$ \\
\hline 2 & $\begin{array}{l}\text { Saya percaya bahwa aplikasi UC } \\
\text { Student dapat memberikan } \\
\text { informasi yang tepat. }\end{array}$ \\
\hline 3 & $\begin{array}{l}\text { Saya percaya aplikasi UC Student } \\
\text { menjaga data pribadi pengguna. }\end{array}$ \\
\hline
\end{tabular}

Tabel 5 Variabel Quality of Information

\begin{tabular}{|c|l|}
\hline No & $\begin{array}{l}|c| \\
\text { Pariabel Quality of Information) }\end{array}$ \\
\hline 1 & $\begin{array}{l}\text { Hasil/output informasi dari } \\
\text { aplikasi UC Student yang saya } \\
\text { gunakan dipresentasikan dalam } \\
\text { format yang tepat. }\end{array}$ \\
\hline 2 & $\begin{array}{l}\text { Informasi dari aplikasi UC } \\
\text { Student yang saya gunakan jelas } \\
\text { dan sesuai. }\end{array}$ \\
\hline 3 & $\begin{array}{l}\text { Aplikasi UC Student yang saya } \\
\text { gunakan menyediakan informasi } \\
\text { yang up-to-date. }\end{array}$ \\
\hline
\end{tabular}

Tabel 6 Variabel Intention to Use

\begin{tabular}{|c|c|}
\hline No & $\begin{array}{c}\text { Pernyataan } \\
\text { (Variabel Intention to Use) }\end{array}$ \\
\hline 1 & $\begin{array}{l}\text { Saya akan terus menggunakan } \\
\text { aplikasi UC Student selama } \\
\text { menjadi mahasiswa. }\end{array}$ \\
\hline 2 & $\begin{array}{l}\text { Saya bermaksud untuk terus } \\
\text { menggunakan aplikasi } \\
\text { Student. }\end{array}$ \\
\hline 3 & $\begin{array}{l}\text { Saya akan menggunakan aplikasi } \\
\text { UC Student ketika saya } \\
\text { membutuhkannya. }\end{array}$ \\
\hline
\end{tabular}

HASIL DAN PEMBAHASAN

\section{Data Responden}

Tabel 7 Data Responden

\begin{tabular}{|l|c|c|}
\hline Jenis Kelamin & Total & Persentase \\
\hline Pria & 54 & $51,9 \%$ \\
\hline Wanita & 50 & $48,1 \%$ \\
\hline Prodi/Jurusan & \multicolumn{2}{|l|}{} \\
\hline ISB & 14 & $13,5 \%$ \\
\hline IMT & 8 & $7,7 \%$ \\
\hline IBM & 15 & $14,4 \%$ \\
\hline BMI & 4 & $3,8 \%$ \\
\hline FDB & 1 & $1 \%$ \\
\hline CB & 3 & $2,9 \%$ \\
\hline INA & 1 & $1 \%$ \\
\hline ACC & 2 & $1,9 \%$ \\
\hline PSY & 21 & $20,2 \%$ \\
\hline VCD & 9 & 8,7 \\
\hline MED & 2 & $1,9 \%$ \\
\hline FIKOM & 7 & $6,7 \%$ \\
\hline FOOD-TECH & 2 & $1,9 \%$ \\
\hline HTB & 50 & $48,1 \%$ \\
\hline Angkatan & $15,4 \%$ \\
\hline 2016 & $28,9 \%$ \\
\hline 2017 & $14,4 \%$ \\
\hline 2018 & & $10,6 \%$ \\
\hline 2019 & & \\
\hline & & \\
\hline
\end{tabular}




\section{Statistik Deskriptif}

Dalam sebuah penelitian sangatlah penting untuk mengetahui seberapa banyak responden yang baik ataupun yang kurang baik sehingga dalam penelitian dapat memperoleh hasil yang diharapkan.

\section{Tabel 8 Statistik Deskriptif Variabel Perceived Usefulness}

\begin{tabular}{|l|c|c|}
\hline $\begin{array}{c}\text { Pernyataan } \\
\text { (Perceived Usefulness) }\end{array}$ & Mean & $\begin{array}{l}\text { Standar } \\
\text { Deviasi }\end{array}$ \\
\hline $\begin{array}{l}\text { Penempatan informasi } \\
\text { pada aplikasi UC }\end{array}$ & 4,32 & 0,596 \\
$\begin{array}{l}\text { Student mempermudah } \\
\text { saya dalam mengakses } \\
\text { informasi. }\end{array}$ & 4,06 & 0,680 \\
\hline $\begin{array}{l}\text { Aplikasi UC Student } \\
\text { dapat memenuhi } \\
\text { kebutuhan saya dalam } \\
\text { mendapatkan tentang } \\
\text { informasi jad } \\
\text { perkuliahan jadwal }\end{array}$ & 4,31 & 0,640 \\
\hline $\begin{array}{l}\text { Aplikasi UC Student } \\
\text { meningkatkan } \\
\text { efektivitas saya dalam } \\
\text { mengakses jadwal } \\
\text { perkuliahan. }\end{array}$ & 4,23 & \\
\hline Total & & \\
\hline
\end{tabular}

Berdasarkan Tabel 8, didapatkan nilai mean pada variabel perceived usefulness adalah 4,23 yang dapat diartikan bahwa responden setuju dengan indikator pernyataan terhadap variabel perceived usefulness. Nilai dari standar deviasi tertinggi ada pada indikator pernyataan kedua (X1.2) yaitu sebesar 0,680 sehingga dapat diartikan bahwa kebutuhan dalam mendapatkan informasi perkuliahan dapat dipenuhi. Sedangkan nilai mean tertinggi ada pada indikator pernyataan pertama (X1.1) yaitu sebesar 4,32 sehingga dapat diberikan kesimpulan bahwa responden setuju dengan indikator dari pernyataan pertama yaitu penempatan informasi pada aplikasi UC Student mempermudah saya dalam mengakses informasi.

Tabel 9 Statistik Deskriptif Variabel Perceived Ease Of Use

\begin{tabular}{|c|c|c|}
\hline $\begin{array}{c}\text { Pernyataan } \\
\text { (Perceived Ease of } \\
\text { Use })\end{array}$ & Mean & $\begin{array}{l}\text { Standar } \\
\text { Deviasi }\end{array}$ \\
\hline $\begin{array}{l}\text { Saya dapat mengakses } \\
\text { aplikasi } U C \text { Student } \\
\text { dengan mudah, kapan } \\
\text { dan dimana saja. }\end{array}$ & 4,25 & 0,650 \\
\hline $\begin{array}{l}\text { Saya tidak perlu } \\
\text { menghabiskan waktu } \\
\text { yang lama untuk } \\
\text { memikirkan bagaimana } \\
\text { cara menggunakan } \\
\text { aplikasi } \\
\text { UC Student. }\end{array}$ & 4,39 & 0,645 \\
\hline $\begin{array}{l}\text { Mudah bagi saya untuk } \\
\text { terampil dalam } \\
\text { menggunakan aplikasi } \\
U C \text { Student untuk } \\
\text { memenuhi apa yang } \\
\text { saya inginkan. }\end{array}$ & 4,28 & 0,645 \\
\hline \begin{tabular}{lr} 
Tampilan & \multicolumn{2}{r}{ antarmuka } \\
aplikasi UC & Student \\
jelas dan & mudah \\
dipahami. &
\end{tabular} & 4,24 & 0,731 \\
\hline Total & 4,29 & \\
\hline
\end{tabular}

Berdasarkan Tabel 9, didapatkan nilai mean pada variabel perceived ease of use adalah 4,29 yang dapat diartikan bahwa responden setuju dengan indikator pernyataan pada variabel perceived ease of use. Nilai tertinggi pada bagian standar deviasi ada pada indikator pernyataan keempat (X2.4) yaitu sebesar 0,731 yang memiliki arti bahwa user interface pada aplikasi UC Student mudah untuk dipahami. Sedangkan nilai mean tertinggi ada pada indikator pernyataan kedua (X2.2) yaitu sebesar 4,39 sehingga dapat disimpulkan bahwa responden setuju dengan indikator dari pernyataan kedua. 
Tabel 10 Statistik Deskriptif Variabel Trust

\begin{tabular}{|l|c|c|}
\hline \multicolumn{1}{|c|}{$\begin{array}{c}\text { Pernyataan } \\
\text { (Trust) }\end{array}$} & Mean & $\begin{array}{l}\text { Standar } \\
\text { Deviasi }\end{array}$ \\
\hline $\begin{array}{l}\text { Aplikasi UC Student } \\
\text { dapat dipercaya oleh } \\
\text { mahasiswa } \\
\text { universitas Ciputra. }\end{array}$ & 4,30 & 0,589 \\
\hline $\begin{array}{l}\text { Saya percaya bahwa } \\
\text { aplikasi UC Student } \\
\text { dapat memberikan } \\
\text { informasi yang tepat. }\end{array}$ & 4,26 & 0,607 \\
\hline $\begin{array}{l}\text { Saya percaya aplikasi } \\
\text { UC Student menjaga } \\
\text { data pribadi } \\
\text { pengguna. }\end{array}$ & 4,21 & 0,720 \\
\hline Total & 4,26 & \\
\hline
\end{tabular}

Berdasarkan Tabel 10 didapatkan nilai mean pada variabel trust adalah 4,26 yang dapat diartikan bahwa responden setuju dengan indikator pernyataan pada variabel trust. Nilai dari standar deviasi tertinggi ada pada indikator pernyataan ketiga (X3.2) yaitu sebesar 0,720 sehingga dapat diartikan bahwa data-data pengguna aplikasi dapat dijaga dengan baik. Sedangkan nilai mean yang tinggi ada pada indikator pernyataan pertama (X3.1) yaitu sebesar 4,30 sehingga dapat diberikan kesimpulan bahwa responden setuju dengan indikator dari pernyataan pertama yaitu aplikasi UC Student dapat dipercaya oleh mahasiswa Universitas Ciputra.

\section{Tabel 11 Statistik Deskriptif Variabel Quality of Information}

\begin{tabular}{|l|l|l|}
\hline \multicolumn{1}{|c|}{$\begin{array}{c}\text { Pernyataan } \\
\text { (Quality of } \\
\text { Information) }\end{array}$} & Mean & $\begin{array}{l}\text { Standar } \\
\text { Deviasi }\end{array}$ \\
\hline $\begin{array}{l}\text { Hasil/output dari } \\
\text { informasi Su } \\
\text { aplikasi UC Student }\end{array}$ & 4,32 & 0,596 \\
$\begin{array}{l}\text { yang saya gunakan } \\
\text { dipresentasikan } \\
\text { dalam format yang }\end{array}$ & & \\
\hline
\end{tabular}

\begin{tabular}{|l|l|l|}
\hline tepat. & & \\
\hline $\begin{array}{l}\text { Informasi dari } \\
\text { aplikasi UC Student } \\
\text { yang saya gunakan } \\
\text { jelas dan sesuai. }\end{array}$ & 4,06 & 0,680 \\
\hline $\begin{array}{l}\text { Aplikasi UC Student } \\
\text { yang saya gunakan } \\
\text { menyediakan } \\
\text { informasi yang up-to- } \\
\text { date. }\end{array}$ & 4,31 & 0,640 \\
\hline Total & 4,18 & \\
\hline
\end{tabular}

Berdasarkan Tabel 11 didapatkan nilai mean pada variabel quality of information adalah 4,18 yang dapat diartikan bahwa responden setuju dengan indikator pernyataan dari variabel quality of information. Nilai dari standar deviasi yang tinggi ada pada indikator pernyataan ketiga (X4.3) yaitu sebesar 0,679 sehingga dapat diartikan bahwa penyediaan informasi pada aplikasi UC Student merupakan terbaru (upto-date). Sedangkan nilai mean tertinggi ada pada indikator pernyataan kedua (X4.2) yaitu sebesar 4,30 sehingga dapat diberikan kesimpulan bahwa responden setuju dengan indikator dari pernyataan kedua yaitu informasi dari aplikasi UC Student yang saya gunakan jelas dan sesuai.

Tabel 12 Statistik Deskriptif Variabel Intention to Use

\begin{tabular}{|c|c|c|}
\hline $\begin{array}{c}\text { Pernyataan } \\
\text { (Intention to Use) }\end{array}$ & Mean & $\begin{array}{l}\text { Standar } \\
\text { Deviasi }\end{array}$ \\
\hline $\begin{array}{lr}\text { Saya akan } & \text { terus } \\
\text { menggunakan } & \\
\text { aplikasi } U C & \text { Student } \\
\text { selama } & \text { menjadi } \\
\text { mahasiswa. } & \end{array}$ & 4,46 & 0,573 \\
\hline $\begin{array}{lr}\text { Saya } & \text { bermaksud } \\
\text { untuk } & \text { terus } \\
\text { menggunakan } \\
\text { aplikasi } & \text { UC Student. }\end{array}$ & 4,14 & 0,703 \\
\hline Saya & 4,37 & 0,541 \\
\hline
\end{tabular}




\begin{tabular}{|l|l|l|}
\hline $\begin{array}{l}\text { menggunakan saya } \\
\text { aplikasi UC Student } \\
\text { ketika } \begin{array}{l}\text { sayanya. } \\
\text { membutuhkannya. }\end{array}\end{array}$ & & \\
\hline Total & 4,32 & \\
\hline
\end{tabular}

Berdasarkan Tabel 12 didapatkan nilai mean pada variabel intention to use adalah 4,32 yang dapat diartikan bahwa responden setuju dengan indikator pernyataan dari variabel intention to use. Nilai dari standar deviasi yang tinggi ada pada indikator pernyataan kedua (Y1.2) yaitu sebesar 0,703 sehingga dapat diartikan bahwa mahasiswa Universitas Ciputra bermaksud untuk terus menggunakan aplikasi UC Student. Sedangkan nilai mean tertinggi ada pada indikator pernyataan pertama (Y1.1) yaitu sebesar 4,46 sehingga dapat diberikan kesimpulan bahwa responden setuju dengan indikator dari pernyataan kedua yaitu saya akan terus menggunakan aplikasi UC Student selama menjadi mahasiswa.

\section{Uji Validitas dan Reliabilitas}

Menurut (Mokoginta, Lambey, \& Potoh, 2017) uji validitas merupakan suatu gambaran pertanyaan yang digunakan dalam penelitian yang mampu memberikan sesuatu yang diukur valid dan jika nilai dari pertanyaan yang digunakan berkorelasi signifikan dari nilai totalnya maka dikatakan valid. Uji validitas memiliki fungsi untuk menentukan suatu instrumen dalam penelitian yang digunakan dapat melakukan fungsinya. Validitas juga merupakan suatu ukuran yang memberikan validitas dari suatu instrumen (Rinabi, 2019).

1. Apabila nilai signifikan $<0,05$ maka dapat dinyatakan valid.

2. Apabila nilai dari signifikan $>0,05$ maka dapat dinyatakan tidak valid.

Pengujian validitas dilakukan dengan menggunakan metode analisis Bivariate
Pearson yang dimana pengujian ini digunakan untuk menghubungkan skor dari item terhadap skor total item, yaitu dengan menggunakan software SPSS 22. Pengujian validitas bisa dikatakan valid jika skor dari item pertanyaan yang ditentukan berkorelasi secara signifikan dengan skor totalnya. Apabila nilai signifikansi $<0,05$ maka dapat dinyatakan valid. Berikut merupakan hasil uji validitas yang dilakukan dalam penelitian:

Tabel 13 Uji Validitas

\begin{tabular}{|c|c|c|c|}
\hline Variabel & Signifikan & $\begin{array}{c}\text { Nilai } \\
\text { Signifikan }\end{array}$ & Note \\
\hline \multicolumn{4}{|c|}{ Perceived Usefulness } \\
\hline PU1 & 0,05 & 0,00 & valid \\
\hline PU2 & 0,05 & 0,00 & valid \\
\hline PU3 & 0,05 & 0,00 & valid \\
\hline \multicolumn{4}{|c|}{ Perceivved Ease of Use } \\
\hline POU1 & 0,05 & 0,00 & valid \\
\hline POU2 & 0,05 & 0,00 & valid \\
\hline POU3 & 0,05 & 0,00 & valid \\
\hline POU4 & 0,05 & 0,00 & valid \\
\hline \multicolumn{4}{|l|}{ Trust } \\
\hline TU1 & 0,05 & 0,00 & valid \\
\hline TU2 & 0,05 & 0,00 & valid \\
\hline TU3 & 0,05 & 0,00 & valid \\
\hline \multicolumn{4}{|c|}{ Quality of Information } \\
\hline QI1 & 0,05 & 0,00 & valid \\
\hline QI2 & 0,05 & 0,00 & valid \\
\hline QI3 & 0,05 & 0,00 & valid \\
\hline
\end{tabular}




\begin{tabular}{|l|l|l|l|}
\hline Variabel & Signifikan & $\begin{array}{c}\text { Nilai } \\
\text { Signifikan }\end{array}$ & Note \\
\hline \multicolumn{3}{|l|}{ Intention to Use } \\
\hline ITU1 & 0,05 & 0,00 & valid \\
\hline ITU2 & 0,05 & 0,00 & valid \\
\hline ITU3 & 0,05 & 0,00 & valid \\
\end{tabular}

Pada Tabel 8 di atas, diketahui bahwa nilai indikator instrumen penelitian dengan sig. (2-tailed) memiliki nilai signifikansi < 0,05, maka dapat disimpulkan bahwa nilai indikator penelitian dinyatakan valid.

Uji reliabilitas merupakan suatu indikator dari variabel atau konstruk yang mengukur suatu kuesioner. Apabila jawaban dari seseorang terhadap pertanyaan konsisten dari waktu ke waktu maka dapat dikatakan reliabel atau handal. Penentuan tinggi rendahnya reliabilitas ditujukan oleh suatu angka yang disebut dengan koefisien reliabilitas(Mokoginta, Lambey, \& Potoh, 2017).

Menurut(Rinabi, 2019) menyatakan bahwa reliabilitas menunjukkan stabilitas dan konsistensi skor (skala dari pengukuran). Uji reliabilitas dilakukan dengan menggunakan pengujian Cronbach Alpha dan apabila nilai dari Cronbach Alpha> 0,7 maka dapat dinyatakan instrumen memiliki reliabilitas dari variabel yang baik.

Berikut merupakan hasil uji reliabilitas:

Tabel 14 Uji Reliabilitas

\begin{tabular}{|l|c|c|}
\hline Variabel & $\begin{array}{c}\text { Total N } \\
\text { Item }\end{array}$ & $\begin{array}{c}\text { Cronbach } \\
\text { Alpha }\end{array}$ \\
\hline PU & 3 & 0,812 \\
\hline POU & 4 & 0,807 \\
\hline TU & 3 & 0,821 \\
\hline
\end{tabular}

\begin{tabular}{|l|l|l|}
\hline QI & 3 & 0,792 \\
\hline ITU & 3 & 0,818 \\
\hline
\end{tabular}

\section{Analisis Regresi Linear Berganda}

Menurut(Mokoginta, Lambey, \& Potoh, 2017) hubungan dari dua atau lebih variabel independen $\left(\mathrm{x} 1, \mathrm{x} 2, \ldots . \mathrm{x}_{\mathrm{n}}\right)$ dengan variabel dependen (y) merupakan analisis regresi linear berganda. Analisis data dilakukan dengan menggunakan bantuan software SPSS dengan persamaan linear berganda sebagai berikut;

$$
Y=\alpha+\beta_{1} X_{1}+\beta_{7} X_{7}+\beta_{n} X_{n}+e
$$

Keterangan

$\mathrm{Y}=$ variabel dependen (terikat)

$\mathrm{X}=$ variabel independen (bebas)

$\alpha=$ konstanta

$\beta=$ koefisien regresi

$\mathrm{e}=$ error

Uji analisis regresi linier berganda digunakan untuk melihat ada tidaknya pengaruh dari dua atau lebih variabel independen terhadap intensi penggunaan aplikasi UC Student yaitu persepsi kebermanfaatan, kemudahan, kepercayaan, dan kualitas informasi. Berikut merupakan hasil uji analisis regresi linier berganda yang dilakukan pada penelitian:

Tabel 15 Analisis Regresi Linear Berganda

\begin{tabular}{|l|c|}
\hline \multicolumn{1}{|c|}{ Variabel } & $\begin{array}{c}\text { Unstandardized } \\
\text { Coefficients }\end{array}$ \\
\cline { 2 - 2 } & $\mathrm{B}$ \\
\hline (Constant) & 1,279 \\
\hline $\begin{array}{l}\text { Persepsi } \\
\text { kebermanfaatan }\end{array}$ & 0,412 \\
\hline Persepsi kemudahan & 0,176 \\
\hline
\end{tabular}




\begin{tabular}{|l|c|}
\hline Kepercayaan & 0,093 \\
\hline Kualitas informasi & 0,036 \\
\hline
\end{tabular}

Dari hasil analisis yang sudah dilakukan, diketahui persamaan regresi sebagai berikut:

$\mathrm{Y}=1,279+0,412 \mathrm{X} 1+0,176 \mathrm{X} 2+0,093$ $\mathrm{X} 3+0,036 \mathrm{X} 4$

Koefisien regresi dari variabel $\mathrm{X} 1$ (persepsi kebermanfaatan) mempunyai nilai sebesar 0,412 yang berarti memiliki pengaruh positif terhadap intensi penggunaan.

Koefisien regresi dari variabel $\mathrm{X} 2$ (persepsi kemudahan) mempunyai nilai sebesar 0,176 yang berarti memiliki pengaruh positif terhadap intensi penggunaan.

Koefisien regresi dari variabel $\mathrm{X} 3$ (kepercayaan) mempunyai nilai sebesar 0,093 yang berarti memiliki pengaruh positif terhadap intensi penggunaan.

Koefisien regresi dari variabel $\mathrm{X} 4$ (kualitas informasi) mempunyai nilai sebesar 0,036 yang berarti memiliki pengaruh positif terhadap intensi penggunaan.

\section{Uji Signifikansi Parsial (Uji t)}

Uji signifikan parsial dilakukan untuk mengetahui apakah variabel independen memiliki pengaruh terhadap variabel dependen. Pengambilan sebuah keputusan berdasarkan pada perbandingan nilai thitung dengan ttabel dan juga berdasarkan nilai signifikan. Dasar pengambilan keputusan yaitu apabila nilai signifikansi $<0,05$ dan nilai thitung > ttabel. Berikut merupakan hasil uji signifikansi parsial yang dilakukan dalam penelitian:

Tabel 16Uji Signifikansi Parsial

\begin{tabular}{|l|c|c|}
\hline & $\mathrm{t}$ & Sig. \\
\hline (Constant) & 3,531 & 0,001 \\
\hline
\end{tabular}

\begin{tabular}{|l|c|c|}
\hline $\begin{array}{l}\text { Persepsi } \\
\text { kebermanfaatan }\end{array}$ & 4,758 & 0,000 \\
\hline Persepsi kemudahan & 2,004 & 0,048 \\
\hline Kepercayaan & 1,101 & 0,273 \\
\hline Kualitas informasi & 0,353 & 0,725 \\
\hline $\begin{array}{c}\text { Berdasarkan } \\
\text { rumus }(\alpha / 2 ; \mathrm{n}-\mathrm{k}-1)\end{array}$ \\
yang dimana;
\end{tabular}

$$
\begin{aligned}
& \alpha=\text { tingkat kepercayaan penelitian } \\
& \mathrm{n}=\text { jumlah sampel } \\
& \mathrm{k}=\text { jumlah variabel independen } \\
& \text { (variabel bebas) }
\end{aligned}
$$

maka dapat mencari nilai $t_{\text {tabel }}$ sebagai berikut;

$$
\begin{aligned}
& \text { ttabel }=\alpha / 2 ; n-k-1 \\
& \text { ttabel }=0,05 / 2 ; 104-4-1 \\
& \text { ttabel }=0,025 ; 99
\end{aligned}
$$

Dari rumus yang sudah ada maka dapat dilihat pada distribusi $t_{\text {tabel }}$ dengan nilai ttabel sebesar 1,984.

Hasil penelitian pada variabel persepsi kebermanfaatan didapatkan hasil bahwa variabel tersebut memiliki pengaruh secara signifikansi parsial dan variabel memiliki arah positif terhadap intensi penggunaan. Dilihat dari nilai yang dihasilkan dari variabel persepsi kebermanfaatan pada uji signifikansi parsial (uji t) nilai t hitung yaitu 4,758 dan nilai $t$ tabel yaitu 1,983. Sesuai dengan dasar pengambilan keputusan, apabila $\mathrm{t}$ hitung lebih besar dari t tabel dan nilai signifikansi lebih kecil dari 0,05 maka variabel tersebut memiliki pengaruh signifikansi parsial terhadap variabel dependen. Hal ini memberikan fakta bahwa variabel persepsi kebermanfaatan dimana membahas mengenai manfaat yang didapatkan terhadap intensi penggunaan aplikasi UC Student. Pada persamaan koefisien regresi linear berganda didapatkan hasil sebesar 0,412, dari hasil tersebut membuktikan bahwa variabel persepsi kebermanfaatan 
mengarah positif. Apabila nilai variabel persepsi kebermanfaatan semakin baik maka semakin baik juga intensi pengguna aplikasi UC Student. Maka hipotesis 1 diterima.

Hasil penelitian pada variabel persepsi kemudahan didapatkan hasil bahwa variabel tersebut memiliki pengaruh secara signifikansi parsial dan variabel mengarah positif terhadap intensi penggunaan. Dilihat dari nilai yang dihasilkan dari variabel persepsi kemudahan pada uji signifikansi parsial (uji t) nilai thitung yaitu 2,004 dan nilai ttabel 1,983. Sesuai dari dasar pengambilan keputusan, apabila thitung lebih besar dari t tabel dan nilai signifikansi lebih kecil dari 0,05 maka variabel persepsi kemudahan memiliki pengaruh signifikansi parsial terhadap intensi penggunaan. Variabel persepsi kemudahan membahas tentang bagaimana suatu aplikasi yang ada dapat dengan mudah untuk digunakan serta mudah untuk dipahami oleh pengguna baik itu dari tampilan maupun isi dari aplikasi tersebut. Pada uji koefisien regresi linear berganda, variabel persepsi kemudahan memiliki nilai sebesar 0,176 dan mengarah positif. Jika variabel persepsi kemudahan semakin baik maka semakin meningkat juga intensi penggunaan aplikasi UC Student. Maka hipotesis 2 diterima.

Hasil penelitian pada variabel kepercayaan didapatkan hasil bahwa variabel tersebut tidak memiliki pengaruh signifikansi parsial (uji t) akan tetapi variabel kepercayaan pada nilai koefisien regresi linear berganda mengarah ke positif terhadap intensi penggunaan. Dari hasil yang didapatkan nilai thitung sebesar 1,101 dan nilai $t$ tabel sebesar 1,983. Sesuai dengan dasar pengambilan keputusan, apabila nilai thitung lebih besar dari nilai ttabel dan nilai signifikansi lebih kecil dari 0,05 maka variabel tersebut memiliki pengaruh secara signifikan parsial. Dari nilai yang ada pada uji variabel kepercayaan, tidak memenuhi dasar pengambilan keputusan. Maka dapat diartikan variabel tersebut tidak berpengaruh terhadap intensi penggunaan aplikasi UC Student, akan tetapi variabel kepercayaan tetap memiliki pengaruh karena nilai dari koefisien regresi linear yang didapatkan yaitu 0,093 yang artinya variabel kepercayaan mengarah ke positif. Dalam hal ini variabel kepercayaan yang dimana membahas tentang kepercayaan pengguna terhadap data dan informasi yang diterima, apakah sesuai dengan harapan atau tidak. Dengan demikian pengguna bukan hanya bisa menggunakan aplikasi dengan mudah melainkan juga data-data dan informasi pribadi pengguna harus tetap aman dan tidak disalah gunakan. Maka hipotesis 3 ditolak.

Hasil penelitian variabel kualitas informasi didapatkan hasil bahwa variabel tersebut tidak memiliki pengaruh secara signifikansi parsial (uji t) akan tetapi variabel kualitas informasi pada nilai koefisien regresi linear berganda mengarah ke positif terhadap intensi penggunaan. Dari hasil yang didapatkan nilai thitung yaitu 0,353 dan nilai ttabel yaitu 1,983 . Sesuai dengan dasar pengambilan keputusan, apabila nilai thitung lebih besar dari nilai ttabel dan nilai signifikansi lebih kecil dari 0,05 maka variabel tersebut memiliki pengaruh secara signifikan parsial. Dengan demikian variabel tersebut tidak memenuhi syarat pengambilan keputusan. Variabel kualitas informasi merupakan variabel yang mendapatkan nilai thitung lebih kecil dari nilai - nilai variabel lainnya. Variabel kualitas informasi membahas tentang informasi - informasi yang ada pada aplikasi, apakah sudah sesuai dengan harapan dari pengguna atau tidak. Nilai dari koefisien regresi linear berganda yaitu 0,036 yang berarti nilai koefisien mengarah ke positif. Semakin besar kualitas informasi yang diterima pengguna maka semakin besar juga intensi penggunaan aplikasi UC Student. Maka hipotesis 4 ditolak.

\section{Uji Signifikansi Simultan (Uji f)}

Uji f bertujuan untuk mengetahui pengaruh variabel independen terhadap niat penggunaan. Pengambilan keputusan 
didasarkan pada perbandingan nilai fhitung dengan ftabel dan juga berdasarkan pada nilai signifikansi. Dasar pengambilan keputusan apabila nilai fhitung $>\mathrm{f}$ tabel dan nilai signifikansi $<0,05$ maka variabel bebas mempengengaruhi variabel terikat secara bersama - sama.

Tabel 17 Uji Signifikansi Simultan

\begin{tabular}{|c|c|c|}
\hline & F & Sig. \\
\hline Regression & 18,867 & $0,000^{\mathrm{b}}$ \\
\hline
\end{tabular}
dimana;

Berdasarkan rumus $(\mathrm{k} ; \mathrm{n}-\mathrm{k})$, yang

$\mathrm{k}=$ jumlah variabel independen (variabel bebas)

$\mathrm{n}=$ jumlah responden (jumlah sampel dalam penelitian)

maka dapat mencari nilai ftabel sebagai berikut;

ftabel $=\mathrm{k} ; \mathrm{n}-\mathrm{k}$

ftabel $=4 ; 104-4$

ftabel $=4 ; 100$

Dari rumus yang sudah ada maka dapat dilihat pada distribusi ftabel dengan nilai ttabel sebesar 2,46 . Nilai dari fhitung yaitu 18,867 lebih besar dari nilai ftabel yaitu 2,46 dan nilai signifikansi yaitu 0,00 lebih kecil dari 0,05. Hasil penelitian dari seluruh variabel independen yaitu persepsi kebermanfaatan, persepsi kemudahan, kepercayaan dan kualitas informasi secara bersama sama memiliki pengaruh secara simultan terhadap intensi penggunaan aplikasi UC Student.

\section{Uji Koefisien Determinasi}

Untuk mengetahui bagaimana kemampuan dari variabel independen dalam mendefinisikan variabel dependen pada penelitian yaitu dengan menggunakan uji koefisien determinasi. Diketahui nilai dari koefisien determinasi yaitu antara 0 hingga 1 (Astuti, Wulan, \& Fathoni, 2019).Dasar pengambilan keputusan uji r2 jika nilai dari signifikansi $<0,05$ maka nilai koefisien determinasi dapat digunakan untuk melihat kontribusi dari variabel bebas terhadap variabel terikat. Berikut merupakan hasil uji koefisien determinasi yang dilakukan pada penelitian:

Tabel 18 Uji Koefisien Determinasi

\begin{tabular}{|c|c|c|}
\hline Model & $\begin{array}{c}\text { Adjusted R } \\
\text { Square }\end{array}$ & $\begin{array}{c}\text { Durbin } \\
\text { Watson }\end{array}$ \\
\hline 1 & 0,433 & 1,792 \\
\hline
\end{tabular}

koefisien determinasi yaitu 0,433 sama dengan 43,3\%. Angka tersebut memiliki arti variabel kebermanfaatan, kemudahan, kepercayaan dan kualitas informasi berpengaruh terhadap intensi penggunaan aplikasi UC Student. Sedangkan sisanya yaitu 56,7\% dipengaruhi dari variabel diluar model regresi ini. Besarnya variabel diluar model regresi biasanya disebut error Nilai koefisien determinasi yaitu antara 0 1. jika nilai koefisien determinasi semakin mendekati 1 berarti memiliki pengaruh yang semakin kuat.

\section{KESIMPULAN}

Berdasarkan dari hasil yang didapatkan dari penelitian yang dilakukan, dan dari hasil analisis regresi linear berganda yang dilakukan pada penelitian ini didapatkan hasil persamaan regresi sebagai berikut:

$Y=1,279+0,412 X_{1}+0,176 X_{2}+0,093$ $\mathrm{X}_{3}+0,036 \mathrm{X}_{4}$

Persamaan regresi yang didapatkan mengarah ke positif terhadap intensi penggunaan. Dengan demikian peneliti menarik kesimpulan sebagai berikut:

Pengaruh variabel persepsi kebermanfaatan terhadap intensi penggunaan aplikasi $U C$ Student mengarah ke positif dan signifikan, dengan nilai dari koefisien regresi sebesar 0,412 dan nilai $\mathrm{t}_{\text {hitung }}$ sebesar 4,758 dengan nilai signifikansi lebih kecil dari 0,05 yaitu 0,000 . Dengan demikian semakin tinggi nilai 
kebermanfaatan, maka semakin besar intensi penggunaan aplikasi UC Student. Maka dengan ini hipotesis 1 diterima.

Pengaruh variabel persepsi kemudahan terhadap intensi penggunaan aplikasi UC Student mengarah ke positif dan signifikan, dengan nilai dari koefisien regresi sebesar 0,176 dan nilai $t_{\text {hitung }}$ sebesar 2,004 dengan nilai signifikansi lebih kecil dari 0,05 yaitu 0,048 . Dengan demikian semakin tinggi nilai variabel kemudahan, maka semakin besar intensi penggunaan aplikasi UC Student. Maka dengan ini hipotesis 2 diterima.

Pengaruh variabel persepsi berdasarkan nilai koefisien yaitu sebesar 0,093 dan nilai dari $t_{\text {hitung }}$ yaitu sebesar 1,101. Dapat disimpulkan variabel kepercayaan tidak memiliki pengaruh signifikan terhadap intensi penggunaan. Maka hipotesis 3 ditolak. Akan tetapi nilai koefisien dari variabel kepercayaan mengarah ke positif terhadap intensi penggunaan aplikasi UC Student. Dengan demikian semakin tinggi nilai kebermanfaatan, maka semakin besar intensi penggunaan aplikasi UC Student. Pengaruh variabel kualitas informasi berdasarkan koefisien regresi yaitu sebesar 0,036 dan nilai dari thitung yaitu 0,039 . Dapat disimpulkan variabel kualitas informasi tidak memiliki pengaruh signifikan terhadap intensi penggunaan. Maka hipotesis 4 ditolak. Namun nilai koefisien variabel kualitas informasi memiliki pengaruh positif. Semakin lengkap informasi yang didapatkan pengguna maka akan semakin meningkat intensi penggunaan.

Setelah melakukan penelitian pada intensi penggunaan aplikasi UC Student masih terdapat beberapa keterbatasan dalam pelaksanaannya. Dalam penelitian ini yaitu dengan menggunakan empat variabel bebas yaitu persepsi kebermanfaatan, persepsi kemudahan, kepercayaan dan kualitas informasi. Keempat variabel bebas tersebut dapat mempengaruhi intensi penggunaan dengan persentase $43,3 \%$. Sisanya yaitu
$56,7 \%$ dipengaruhi oleh variabel-variabel lain diluar dari penelitian ini.

\section{DAFTAR PUSTAKA}

Astuti, F. D., Wulan, H. S., \& Fathoni, A. (2019). Organizational Commitment, Organizational Climate, and Job Security Towards Turnover Intention and Job Satisfaction As Mediating Variables at PT. Senat Garment. Journal of Management, 1-8.

Bergin, T. (2018). An Introduction to Data Analysis Quantitative, Qualitative and Mixed Methods. Los Angeles: SAGE Publications.

Mokoginta, N., Lambey, L., \& Potoh, W. (2017). Pengaruh Sistem Pengendalian Intern dan Sistem Akuntansi Keuangan Daerah Terhadap Kualitas Laporan Keuangan Pemerintah. Jurnal Riset Akuntansi, 874-890.

Rachmawati et.all., Y. (2018). Potret Pendidikan Indonesia Statistik Pendidikan Indonesia . Jakarta: Badan Pusat Statistik.

Rhee, B. (2019). An Analysis Of Information and Communication Technology and Virtual Reality Technology Implementation Through a Quantitative Research on Users Experiences. Journal of Theoretical and Applied Information Technology, 4797-4810.

Rinabi, T. (2019). What Is The Most Influential Factor On Decisions Using Youtube As A Tool to 
Support Buy or Sell Means? (Case

Study Surabaya City and

Surrounding Area). Journal of

Theoretical and Applied Information

Technology, 2406-2418.

Rozieqy, A., \& Arifin, R. (2018). Pengaruh

Kemudahan, Kepercayaan, Kualitas

Informasi dan Media Sosial

Terhadap Keputusan Pembelian

Secara Online Pada Shopee.co.id.

Jurnal Ilmiah Riset Manajemen, 46-

56.

Rukmiyati, N. S., \& Budiartha, I. (2016).

Pengaruh Kualitas Sistem Informasi,

Kualitas Informasi dan Perceived

Usefulness pada Kepuasan

Penggunaan Akhir Software

Akuntansi (Studi Empiris pada Hotel

Berbintang di Provinsi Bali). Jurnal

Ekonomi dan Bisnis Universitas

Udayana, 115-142.

Sartika, D., \& Yuliantoro, R. (2019).

Pengaruh Kualitas Sumber Daya

Manusia, Pemanfaatan Teknologi

Informasi, dan Sistem Pengendalian

Intern Terhadap Keandalan

Pelaporan Keuangan Pemerintah

Desa Kabupaten Belitung Timur.

Repository Universitas Ahmad

Dahlan, 1-20.

Siregar, M. S., Dalimunthe, S., \&

Trijuniyanto, R. S. (2019). Pengaruh

Profitabilitas, Ukuran Perusahaan,

Kebijakan Dividen dan Struktur

Modal Terhadap Nilai Perusahaan

Pada Perusahaan Manufaktur yang

Terdaftar di Bursa Efek Indonesia

Periode 2015-2017. Jurnal Riset

Manajemen Sains Indonesia, 356-

385.
Sukma, E. A., Hadi, M., \& Nikmah, F. (2019). Pengaruh Technology Acceptance Model (TAM) dan Trust Terhadap Intensi Penggunaan Instagram. Jurnal Riset Ekonomi dan Bisnis, 122-121.

Triana, K. S., Kurniawan, P. S., \& Dewi, P. E. (2018). Pengaruh Persepsi Kemudahan, Persepsi Kebermanfaatan, Computer Self Efficacy, dan Kesesuaian Tugas Terhadap Penggunaan Sistem Keuangan Desa (Studi Kasus pada Desa-Desa Penerima Dana Desa Sekabupaten Buleleng). Jurnal Ilmiah Mahasiswa Akuntansi, 63-72.

Tulodo, B. A., \& Solichin, A. (2019). Analisis Pengaruh Kualitas Sistem, Kualitas Informasi dan Perceived Usefulness Terhadap Kepuasan Penggunaan Aplikasi Care dalam Upaya Peningkatan Kinerja Karyawan (Studi kasus PT. Malacca Trust Wuwungan Insurance, Tbk). Jurnal Riset Manajemen Sains Indonesia, 25-43. 